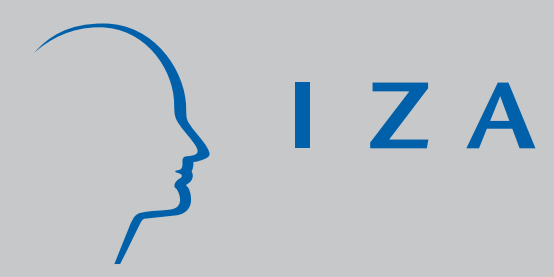

IZADP No. 2662

Principals as Agents? Investigating Accountability in the Compensation and Performance of School Principals

Sherrilyn M. Billger

March 2007 


\title{
Principals as Agents? Investigating Accountability in the Compensation and Performance of School Principals
}

\author{
Sherrilyn M. Billger \\ Illinois State University \\ and IZA
}
Discussion Paper No. 2662
March 2007

IZA
P.O. Box 7240
53072 Bonn
Germany

\author{
Phone: +49-228-3894-0 \\ Fax: +49-228-3894-180 \\ E-mail: iza@iza.org
}

\begin{abstract}
Any opinions expressed here are those of the author(s) and not those of the institute. Research disseminated by IZA may include views on policy, but the institute itself takes no institutional policy positions.

The Institute for the Study of Labor (IZA) in Bonn is a local and virtual international research center and a place of communication between science, politics and business. IZA is an independent nonprofit company supported by Deutsche Post World Net. The center is associated with the University of Bonn and offers a stimulating research environment through its research networks, research support, and visitors and doctoral programs. IZA engages in (i) original and internationally competitive research in all fields of labor economics, (ii) development of policy concepts, and (iii) dissemination of research results and concepts to the interested public.
\end{abstract}

IZA Discussion Papers often represent preliminary work and are circulated to encourage discussion. Citation of such a paper should account for its provisional character. A revised version may be available directly from the author. 


\section{ABSTRACT \\ Principals as Agents? Investigating Accountability in the Compensation and Performance of School Principals}

In this study I examine the relationship between accountability (e.g., state sanctions for poor performance, or the presence of goals required by the district) and public secondary principal pay and school performance. Though such incentives and standards are increasingly common, the existing literature provides little evidence on the effectiveness of these policies. I explore cross-sectional variation in data from the Schools and Staffing Survey, and use quantile regressions where the conditional distributions of pay and school outcomes reflect variation in performance that is not observable in the data. I find that accountability coincides with lower college matriculation rates and lower principal pay, particularly for the best principals. On the other hand, accountability corresponds to higher retention rates at the worst schools. Though they may not be directly rewarded, school principals appear to act as agents for students in danger of dropping out.

JEL Classification: J3, J48, 122

Keywords: pay for performance, school principals, school accountability, education finance

Corresponding author:

Sherrilyn M. Billger

Department of Economics

Illinois State University

Campus Box 4200

Normal, IL 61790-4200

USA

E-mail: smbillg@ilstu.edu

\footnotetext{
* I thank Dan Rich, Kevin Hallock, and participants at SOLE and CeMENT for helpful discussion and comments. I am also very grateful for the helpful suggestions from two anonymous referees.
} 


\section{School Principals and Quality Improvements}

School principals are essential to improvements in school quality, presumably acting as agents for parents, school boards, and communities. In order to align the interests of all constituents, accountability standards have been implemented in many schools, tying compliance to school resources, reputation, and at times, educator pay. Indeed, as Cooley and Shen (2003) state, the school principal is "the key to accountability." Unfortunately, little is known about either the specific role of principals in generating school performance or the factors that enable a principal to respond to incentives and improve school quality. To investigate these issues, this study examines the relationship between accountability and principal compensation and student outcomes, noting factors that likely hinder or enable improvement. In this context, accountability includes districtand school-level factors such as performance goals, school reports, and sanctions, as well as statelevel sanctions for poor performance. A school is assumed to be "accountable" if it faces at least one of these measures, regardless of whether it has directly faced sanctions.

The relationship between accountability and salary or school performance reveals the manner in which school principals act as agents. I examine the relationship between a principal's performance and pay in a few distinct ways. First, the marginal effect of principal characteristics on salary reflects, the "returns" to, for example, education or experience. Well-worn OLS techniques reveal the returns for principals who earn salaries near the median of the overall distribution. I augment these results using quantile regression, where estimates are obtained across the conditional salary distribution. Therefore, comparisons can be made from the lowest through the highest paid. Since quantile regression does not involve partitioning the data by values of the dependent variable, these comparisons are particularly meaningful.

Controlling for principal and school characteristics that are known to significantly determine salary, remaining variation is due to factors unobserved in survey data. These factors may include 
communication skills, motivation and effort, local/state politics, and the principal's leadership ability. Most of these reflect how well a principal functions on the job, and similar to interpretations in some other salary studies, the error distribution reveals variation in performance. Therefore, comparing parameter estimates throughout the conditional distribution of salary reveals whether returns to experience and other credentials are greater for the best-performing or the worstperforming principals. In this study, I specifically focus on the relationship between accountability (such as the presence of required goals from the district) and principal salary. Results imply which principals are likely penalized or rewarded in the presence of these standards. In this way, quantile regression provides a unique opportunity to learn about the heterogeneous incidence and potential effectiveness of new accountability measures.

I then apply a similar method for school outcomes that reflect principal performance. I investigate whether accountability — the possibility of district sanctions for poor performance, for instance-coincides with better outcomes, as measured by college attendance and HS retention rates. As above, the conditional distribution of school outcomes reflects school (and principal) performance. Controlling for finances, school size, pupil-teacher ratios, poverty rates, etc., variation in the school outcome is likely explained by a principal's particular managerial skill, as well as their ability to motivate teachers and students. Therefore, we can learn whether accountability standards correspond to better performance from the best or the worst principals.

I address these issues with national cross-sectional data on secondary schools, using OLS and quantile regressions, as well as two-stage models to address potential endogeneity. If the intention of accountability is to reward the best principals and punish the worst, these standards should be negatively correlated with bad performance and positively correlated with good performance. Alternatively, if accountability is meant to induce better outcomes for struggling schools, we would expect positive relationships among the worst schools, and no significant impact 
at the best. Results presented in this study suggest that accountability corresponds to larger cuts in compensation for the best principals, rather than the worst. I also find that accountability coincides with lower college matriculation rates for students, with stronger evidence for the (conditionally) worst schools. On the other hand, incentives may remedy drop-out problems at (conditionally) low quality schools, though some evidence suggests that high quality schools which are required to meet goals have lower retention rates.

2 School Principals, Student Outcomes, and Accountability

\subsection{Pay for Performance for School Managers}

A school principal manages a school by hiring and evaluating teachers, organizing curricula, and setting standards and policy for students, faculty, and staff, among other tasks. Though other constituents such as the district, the school board, teacher unions, and parents impact the functioning of a school, the principal is primarily responsible for the school's operation. The principal is therefore expected to make decisions that reflect the best interest of the district and the school board. In this way, the principal is the agent and the district/school board is the principal, and principal-agent models for firm managers (e.g., CEOs) are theoretically relevant to understanding principals as school managers.

For instance, to align interests, a firm manager's compensation is correlated with the performance of the firm. The link between stock returns and pay is well-documented (see, e.g., Jensen and Murphy (1990), Gibbons and Murphy (1990), Hallock and Murphy (1999), and Hallock et al. (2003)). On the other hand, measuring performance in not-for-profit organizations is certainly more complex, as there are no clear indicators such as stock prices. Nonetheless, Hallock (2002) reports several important determinants for the salaries of managers at charitable and religious non-

profit firms. For instance, Hallock finds some evidence that fiscal responsibility, measured by 
fraction of expenses on program services, increases salary. Also, similar to for-profit firms, size (and hence responsibility) is rewarded with higher salaries. Indeed, schools with higher enrolments may also offer higher salaries, ceteris paribus, reflecting the increased demands associated with more students.

A principal's salary is also determined by expertise, as measured by education and experience. For example, Stone (1985) finds that education, experience, and district environment are positively correlated with pay. In addition, using New York state data, Ehrenberg et al. (1988) find that the salary of school superintendents is positively impacted by low tax rates and high student achievement on test scores. Meier and O’Toole (2002) study superintendents in Texas schools, finding that revenue per pupil, experience, education, and past school performance on test scores are important salary determinants. Testable hypotheses for models of principal salary therefore include: better school performance is more strongly correlated with salary for the best principals, returns to size should be positive, and returns to expertise increase dispersion in principal salaries.

\subsection{School Accountability}

The implementation of accountability standards for educators reveals an assumption that educators impact student outcomes. There is indeed evidence that principals affect school performance. Eberts and Stone (1988) find that principals impact student achievement through curriculum choices, evaluating teachers, and appropriately allocating teachers' time. Brewer (1993) finds that principals can affect test scores by hiring good teachers and setting academic goals. Principal salaries are also positively related to test score gains. In addition, Ballou and Podgursky (1995) reveal teachers' impressions of the factors that reveal a high-performing principal. They cite teaching experience as being particularly important, though it is unclear whether the value arises from the expertise or the (potential) empathy. 
Clear policy implications arise from empirical analyses of principal salary and school performance. As schools, districts, and states increasingly measure and demand "accountability," the role of the principal in improving school outcomes becomes even more important. A relevant body of literature examines the impact of incentives and accountability on educators and schools. Jacobson (1989) examines a New York state school district that implemented an incentive pay plan aimed at reducing absenteeism. Specifically, teachers received a bonus for each day absent less than seven. Though teachers did not know the exact amount of the bonus they would receive, absenteeism was substantially reduced as a result of the plan. Ladd (1999) investigates the Dallas school accountability and incentive program using panel data for urban schools in Texas. She finds that the program positively impacted seventh grade test scores, though only for whites and Latinos. In addition, dropout rates significantly declined in Dallas relative to other schools, suggesting another positive effect of school accountability. Furthermore, using NAEP data, Palmer (2002) finds that financial incentives linked to statewide tests are positively correlated with student improvements in reading.

While test score gains comprise a common measure of school performance (see Hanushek et al. (1996), Eberts and Stone (1988), and Brewer (1993)), additional measures of performance are likely to be relevant. For instance, the percentage of students who pursue a college education after H.S. graduation is an important measure of performance, and it is apparent that many consider college matriculation an important indicator of a school's success. Another possibility is a school's drop-out rate, which is particularly relevant for struggling schools. Furthermore, it is entirely possible that accountability standards have heterogeneous impacts on educational outcomes.

\subsection{The Impact of Accountability on School Principals}

Presumably, if a school must meet a certain performance goal, the principal is primarily responsible for the goal's attainment. I therefore investigate how principals react to accountability 
standards. One aspect of this topic is the manner in which accountability affects the best and the worst principals and schools.

It is reasonable to expect a monotonic increasing impact of accountability on school performance. That is, the best schools are likely to experience the most positive relationship between accountability and performance, perhaps due to involved parents who want the school to succeed, or because the principal is a great manager who hires the right people and sets appropriate goals. Perhaps the best schools simply have the best resources, and are thus well-equipped to meet any goals or standards set for them. The weakest schools are likely to experience stronger negative correlations between accountability and performance, if such standards are purposefully placed in struggling schools. On the other hand, accountability standards are arguably meant to aid the schools that appear to be the weakest. A more positive correlation for weaker schools could be due to daring principals (with little to lose), educators worried about losing their jobs, or "teaching to the test" and similar activities in order to meet standards. A variety of hypotheses are certainly plausible, as we can expect that the effects of standards depend upon (unobserved) school performance or quality.

This analysis incorporates not only accountability indicators, but also controls for factors that are likely to influence a principal's efficacy in implementing improvements. Such factors include: parental involvement, the principal's relationship with the teaching staff, barriers to dismissal (e.g., from unions), problems with students, and autonomy in hiring teachers and in setting performance standards for students. For instance, the worst principals may be unable to make substantial changes if parents are not involved, or if it is very difficult to dismiss poor teachers. Indeed, a negative relationship between accountability and performance may be due to any or all of these problems. On the other hand, principals who thrive with such standards may do so because, for instance, they are able to exercise considerable influence over curriculum and hiring teachers. 
3 Data and Estimation Techniques

\subsection{Data Sources}

The majority of the data for the secondary schools in this study are compiled from the 19992000 restricted-use Schools and Staffing Survey (SASS) administered by the National Center for Education Statistics. Information from the SASS about districts, principals, and schools is combined with drop-out rate data from the 1999-2000 Common Core of Data. In addition, community characteristics from the 2000 U.S. Census are merged to the school-level data by zip code.

The SASS data provide detailed information on public secondary school principals, including demographic characteristics, as well as specific tasks and assessments of school problems and strengths. For instance, a principal's self-reported influence over curriculum and hiring is available. Particularly valuable are data on accountability. For example, schools that must meet goals from their districts are identified, as well as schools in states with sanctions for poor performance. Furthermore, the cross-sectional variation in the SASS reveals which schools, which principals, and which accountability measures are most highly correlated with strong (and weak) school performance. Particular student outcomes used to measure school performance include the percentage of previous year's seniors who pursued a 4-year college education and the retention rate (based upon the $9^{\text {th }}-12^{\text {th }}$ grade drop-out rate).

Summary statistics for the secondary schools in this analysis appear in Table $1 .^{1}$ Public school principals earn $\$ 67,028$ on average, have taught for 14 years, and have over 8 years of experience as a principal. Average HS enrolment is 729 , which is very close to the statistic reported in the Common Core of Data (CCD) for the same year. The school-level pupil-teacher ratio in this

\footnotetext{
${ }^{1}$ Descriptive statistics are reported for bootstrap samples of 5000 observations (also used in regression analyses below),
} generated using NCES sampling weights. Appropriately weighted means from the original sample are virtually identical. 
sample is 15 , and is slightly lower than the district-level ratio (16) reported by the CCD. On average, $53 \%$ of expenditures are used for instruction, and core expenditures per pupil average $\$ 4185$. Nearly all schools receive performance reports from their districts, while $81 \%$ of schools are required to meet specific goals. A majority $(63 \%)$ of schools in this sample are located in states that sanction poor performance, while only $17 \%$ of principals faces possible sanctions from their district. Not all districts with sanctions are located in states with sanctions. Fifty percent of principals in the sample claim to have greater influence on standards for students than their districts, school boards, or state education departments, and influence on hiring teachers is even more extensive. Finally, as measures of school performance, $42 \%$ of public high school seniors pursued 4-year college education, and the average $9-12^{\text {th }}$ grade dropout rate is $7 \%$. This is the event dropout rate provided by the district for how many students dropped out in the previous year, as contrasted with the oftreported status drop-out rate among all individuals aged 16-24, detailing how many people in that age group are HS drop-outs.

\subsection{OLS Regression Specification}

If school principals act as agents, their salary should reflect their expertise and performance on the job. A baseline specification for the determinants of salary is generated with a simple OLS regression:

$$
E(\text { lsalary } \mid x)=x \beta
$$

Here $x$ is a matrix of principal, school, district, and community characteristics. Parameter estimates reveal mean effects, as $E($ lsalary $\mid x)$ represents the conditional mean of lsalary. For example, the coefficient on teaching experience reveals the mean impact on salary from an additional year of teaching experience. The variation in salary contributing to this impact is due to teaching experience and unobservable factors that are contained within the error term, $\varepsilon$, so that the estimated OLS parameter is the impact of experience at the mean of $\varepsilon$. Assuming that all relevant information is 
already included in the regression, the residual reflects variation in salary that is either due to random luck or performance that is unobserved by researchers. Presumably, if principals are agents, their salary reflects their performance on many tasks that are not included in a survey such as the SASS. Thus, the mean of the conditional salary distribution is assumed to represent the mean unobserved performance. $^{2}$ This notion of unobserved performance is very similar to the convention in the labor economics literature in which the error term reflects innate ability (see, e.g., Arias et al. (2001), Schultz and Mwabu (1998), and Billger (2003)).

The initial specification for the determinants of a public secondary school principal's salary includes a variety of covariates that have been reported in previous studies. ${ }^{3}$

$$
\text { lsalary }=\alpha_{s}+P \beta_{s}+S_{s} \gamma_{s}+C \delta_{s}+A \eta_{s}+\varepsilon_{s}
$$

where $P$ includes characteristics of the principal: highest degree attained, age, experience as teacher, experience as principal, gender, and race/ethnicity, and the $S$ subscript denotes parameters for this salary model. School characteristics are in the vector $S_{\mathrm{S}}$ : urban location indicators, $\ln ($ enrolment), percentage minority enrolment, pupil-teacher ratio, $\ln$ (per pupil expenditures), percentage of expenditures for instruction, and percentage of students eligible for free lunch. Community characteristics from the Census (merged by zip code) are represented by $C$, and include the percentage of households with children and the percentage of the adult population with a BA or BS. Accountability measures are contained in $A$ and include 1) principal reports that the district and/or state requires the school to meet specific educational goals, 2) the school receives a performance report from the district, 3) the school is located in a state that sanctions districts for poor performance, and 4) the school is in a district that sanctions schools for poor performance.

\footnotetext{
${ }^{2}$ It may certainly be true that residual variation results from factors other than performance, but it nevertheless seems reasonable to assume that higher conditional salaries are largely determined by the strong performance of the principal. ${ }^{3}$ Previous studies incorporating similar variables include Stone (1985), Ehrenberg et al. (1988), Ballou and Podgursky (1995), and Meier and O’Toole (2002).
} 
Additional variables about the structure of principal pay would certainly contribute to this analysis. For instance, the presence of merit pay may correlate with salary levels. It would also be interesting to know how much of pay depends upon performance goals, and how large merit bonuses are. Unfortunately, the 1999-2000 SASS survey does not report this information. There is some data about whether teachers could receive merit pay, but no specific amounts are revealed. It is indeed possible that schools with merit pay for teachers also have it for principals, but without solid data, there is no way to be certain. Thus, the omitted principal salary structure variables could lead to biased results on the accountability parameters. Perhaps the marginal effect of required goals and state sanctions is much lower when principals face formal incentive pay structures.

I also consider two educational outcomes that reflect school performance: the college attendance rate and the student retention rate.

$$
\text { outcome }_{j}=\alpha_{j}+S_{O} \gamma_{j}+C \delta_{j}+A \eta_{j}+\varepsilon_{j}
$$

where $j$ takes two values: 1) the percentage of last year's graduates who have decided to pursue further education at a 4-year college, and 2) the school's retention rate, defined as 100 minus the $9^{\text {th }}$ $12^{\text {th }}$ grade dropout rate. The school characteristics $\left(S_{\mathrm{O}}\right)$ expected to relate to these outcomes include $\ln ($ enrolment), percentage minority enrolment, pupil-teacher ratio, school location, $\ln ($ per pupil expenditure), student attendance rate, and free lunch eligibility. Community characteristics $(C)$ and accountability variables $(A)$ are as defined for equation (2) above.

\subsection{Quantile Regression}

As discussed above, the error term in salary regressions reflects unobserved performance. Positive correlations between unobserved performance $(\varepsilon)$ and expertise reveal that the best principals see higher returns to their education and experience. Positive relationships between unobserved performance and accountability measures similarly suggest that, in the presence of such 
standards, better principals receive greater rewards, in that their salary is significantly augmented when accountability measures are in place.

To investigate these relationships, quantile regressions provide parameter estimates throughout the conditional distribution of the dependent variable. ${ }^{4}$ Results reveal the effect of the covariates on the dependent variable across higher and lower values of the error term. For instance, lower quantiles of the conditional distribution of principal salary represent the principals who receive low salaries, given their education and experience and school and community characteristics. Where OLS provides a single parameter estimate for the mean of the conditional distribution of salary, quantile regression estimates reveal variation across the distribution of pay. In other words, OLS provides the solution to minimizing the weighted sum of squared residuals, while a particular $\theta^{\text {th }}$ regression quantile is the solution to

$$
\min _{\beta \in R^{K}}\left[\sum_{i \in\left\{i: y_{i} \geq x_{i}^{\prime} \beta\right\}} \theta\left|y_{i}-x_{i}^{\prime} \beta\right|+\sum_{i \in\left\{i: y_{i}<x_{i}^{\prime} \beta\right\}}(1-\theta)\left|y_{i}-x_{i}^{\prime} \beta\right|\right]
$$

where $\theta \in(0,1)$. This involves the weighted sum of absolute deviations, obtaining particular quantiles by appropriately weighting the residuals.

As a corollary to the OLS specification presented in (1), the follow regression is estimated:

$$
\operatorname{Quant}_{\theta}(y \mid x)=x \beta_{\theta}
$$

where $y$ is the dependent variable, alternately $\ln$ (salary), college attendance, and retention rate. $\theta$ represents the quantile in the conditional distribution of $y . \quad \theta=0.5$ corresponds to the conditional median, and remaining quantiles reflect differential weighting of the positive and negative residuals. For instance, parameter estimates at $\theta=0.1$ reveal the marginal impact at the tenth percentile of the

\footnotetext{
${ }^{4}$ Koenker and Hallock (2001) provide an introduction to the quantile regressions technique that is developed in Koenker and Bassett (1978).
} 
conditional salary distribution. This is certainly not identical to partitioning the data and running a regression with only the lowest $10 \%$ of salary earners.

In quantile regressions of $\ln$ (salary), the conditional distribution is related to the unobserved performance of the school principal. A similar interpretation applies to regressions of educational outcomes such as test scores and college attendance rates, wherein the conditional distribution reflects unobserved performance of the school. Some previous studies use quantile regression in this manner. For example, Levin (2001) finds that lower-ability students receive the most substantial gains from taking classes with peers of similar ability. Eide and Showalter (1998) find that per-pupil expenditures significantly impact test scores for only the lowest-performing students. Figlio (1999) also finds that coefficient estimates differ through conditional quantiles. In this study I estimate regressions for salary and for school outcomes, incorporating indicators of accountability. Thus, quantile coefficient estimates reveal the correlation between accountability and unobserved performance.

\subsection{Principal Authority and Autonomy}

Principals are managers for their schools, but they generally do not have the same power that private sector corporate managers have. As Chubb and Moe (1988) state, "the principal operates at the boundary of the organization and is, more than any other single person, responsible for negotiating successfully with the environment—responding to demands and pressures from parents, unions, administrators, and school boards, and dealing with external disruptions such as budget cuts, policy conflicts, and demographic changes" (p. 1077). So many stakeholders may well hinder a principal's effectiveness. Within this environment, it is essential for principals to have clear goals, rigorous academic requirements, autonomy from school boards, and strong teacher and parent involvement. Friedkin and Slater (1994) further highlight the importance of principal-teacher relations. If teachers respect the principal, they are likely more responsive to advice and will more 
easily integrate a principal's goals throughout the school. Unfortunately, much of the data required to adequately address these issues is not available, but the SASS does provide some measures of principal authority and autonomy. ${ }^{5}$

I consider the following factors: 1) the principal's influence on student performance standards exceeds the district's, 2) the principal's influence on hiring exceeds the district's, 3) the principal's influence on hiring exceeds the teachers', 4) the principal claims there is a serious problem with parental involvement at the school, and 5) the district has a bargaining agreement with teachers (a barrier to dismissing teachers). The role of these in pay and performance is discussed further in section 4 .

It is possible that other factors could also reflect a principal's power in a school. Potentially relevant options include the principal's overall rating of teaching staff (a signal of an amicable relationship with teachers) and the presence of problems with violence and drugs. However, the inclusion of these two controls had no clear impact on results, and they are omitted because they reflect factors that are likely captured in other covariates.

\subsection{Potential Endogeneity in Accountability, Principal Salary, and School Outcomes}

Any significant relationship between accountability and salary could certainly reflect endogeneity. That is, the unobserved factors that cause a school to face required goals may be correlated with the unobservable characteristics of the principal, yielding parameter estimates that do not reveal the true relationship. For instance, if poor teacher contributes to low retention rates, it is quite possible that poor teaching also coincides with required goals for the entire school. To address this sort of endogeneity, I use 2SLS and two-stage least absolute deviation (2SLAD) models. ${ }^{6}$

\footnotetext{
${ }^{5}$ Ballou and Podgursky (1995) study teacher ratings of principals. These data are provided by teachers, with only a very small sample of them from each school. Rather than derive averages in that case, I incorporate principal-level data instead.

${ }^{6}$ Evaluating the instruments according to the discussion in Bound et al. (1995) reveals that state effects are quite good instruments for all accountability measures, though weaker for required goals.
} 
Initially, revisit equation (3) for college attendance rate:

$$
\text { college attendance }=\alpha+S_{O} \gamma+C \delta+A \eta+\varepsilon
$$

where $A$ are accountability variables, each of which may be endogenous. For an individual accountability variable_-district sanctions, for example_consider a simple model:

$$
\text { district sanctions }=X \zeta+Z \varphi+v
$$

where $X$ contains all exogenous variables (those within $S_{O}$ and $C$ ) and $Z$ are instruments correlated with district sanctions but not with the percentage of students attending college. If $A$ and $\varepsilon$ are significantly correlated, accountability measures are endogenous.

2SLS involves first stage OLS regressions like equation (7) for all endogenous variables, obtaining predicted values to use in subsequent estimation of equation (6). 2SLAD was developed by Amemiya (1982) and is very similar, with first-stage OLS to obtain predicted values, and secondstage quantile regressions. For reliable standard errors with 2SLS, I simultaneously estimate the first- and second- stage equations. In addition, 2SLAD estimates result from 1000 bootstrapping repetitions.

Valid instruments are especially important for these techniques. I use state fixed effects, which are correlated with accountability through policies and state/regional differences in school administration. It is possible that states also vary in the main outcomes (salary, college matriculation, and retention). However, it is not likely that state fixed effects are correlated with these variables in models that control for school and community characteristics; the conditional correlation is likely quite small. Average differences in salaries and student outcomes do exist across states, but these trends are largely determined by school, district, and community characteristics, which are included in the structural models in this analysis.

To strengthen this intuitive explanation I have also tested the quality of state fixed effects as instruments. The importance of quality instruments is well-known, and my method is informed by 
Bound et al. (1995) and Stock and Yogo (2005). I first separately test for endogeneity for each accountability variable. I use only significant regressors from the structural model, such as equation (6), and then estimate the reduced form for each measure, such as equation (7). From this I obtain residual estimates $\hat{v}$, and I then include these to the structural models. F-tests on the joint significance of the parameters on the predicted residuals reject the null in most cases; it appears most accountability measures are indeed endogeneous.

I proceed to check the strength of the state fixed effect instruments in the reduced form regressions like equation (7). In all cases - for all outcomes of interest - the F-tests result in pvalues that are equal to zero. Furthermore, most F-statistics are quite high, well over 10 and sometimes over 100. I further discuss the validity of state fixed effects as instruments for each outcome in the results section below. I also considered other instruments that seem highly correlated with accountability but may not be correlated with salary or school outcomes: a measure of a principal's influence on standards (relative to the state) and an indicator of merit pay for teachers. While both are unconditionally correlated with the accountability variables, they are not conditionally correlated. In the first stage regressions that include school and community covariates, the parameters on relative influence and teacher merit pay do not test significantly different from zero, so neither measure is a good instrument for accountability.

\section{Principal Pay and Performance}

\subsection{Principal Salary}

Estimation results for equation (2) appear in Table 2. Standard errors are robust to heteroskedasticity, and quantile regression estimates result from 1000 bootstrapping repetitions. Accountability standards are negatively correlated with principal salary throughout the conditional salary distribution. Schools that are required to meet goals and schools whose states or districts 
sanction poor performance pay lower salaries, ceteris paribus. It also appears that the relationship between accountability and pay is not uniform across schools. That is, F-tests for equality of estimates across conditional quantiles reveal that mean estimates do not reflect the entire distribution of effects.

It appears that principals are paid less if they manage in a district that sanctions some schools (regardless of whether their school is sanctioned). This relationship explains some of the particularly lower salaries. Stated differently, more negative estimates at lower quantiles suggest that the worst principals appear in districts that use sanctions. Given that the data are cross-sectional and not longitudinal, the duration of such accountability is unknown. Perhaps the standards were only recently implemented, and negative correlations therefore simply reveal that lower-paid principals are at schools with this accountability. Coefficient estimates that become less negative toward upper quantiles suggest that the largest wage penalties associated with facing standards are placed on the worst principals. In addition, it appears that principals are not better paid, nor do they perform better in response to standards, in that schools with standards offer lower salaries.

Coefficient estimates for most additional regressors appear in Figure 1. Each graph displays parameter estimates for quantiles in the conditional distribution of $\ln ($ salary). OLS estimates only the mean effect, and each dotted line reveals the single OLS parameter for each covariate. Quantile regression estimates are plotted from 0.05 through 0.95 , surrounded by $95 \%$ confidence intervals. If these estimates deviate substantially from the dotted line, quantile regression imparts valuable additional information about the variation in effects throughout the conditional salary distribution. The returns to experience appear quite well-estimated by OLS, but the mean impact of school size is upward biased for the best-paid principals. If quantiles in the conditional salary distribution reflect unobserved performance, the worst principals receive a higher return than the best. Another explanation for this result is that school size compresses principal salaries, augmenting otherwise low 
pay. Per-pupil expenditures appear uniformly correlated with principal salaries, but instructional expenditures yield significantly lower pay near the median of the salary distribution. On the other hand, the negative relationship is weaker for the best- and the worst- paid principals.

Returning to accountability, it remains possible that the impact of accountability reflects, at least in part, a principal's inability to make institutional changes that will improve the school and his or her salary. To investigate this, I incorporate additional authority/autonomy controls as described in section 3.4 above. In Panel B of Table 2 we see that the negative relationship between required goals and salary remains, and generally decreases in magnitude in higher quantiles of the conditional distribution of salary. This is also true for the presence of district or state sanctions for poor performance. The negative correlation remains between low-performing principals and lower salaries in the presence of accountability; it does not appear mitigated by principal autonomy. However, as seen in the top quantile estimates, the highest paid principals may indeed be so highly paid because of their extensive influence on performance standards and parental involvement problems that they encounter. F-test results for the equality of coefficients across the quantiles reveal that these effects are not equal throughout the distribution of unobserved principal performance.

I next address endogeneity using 2SLS and 2SLAD, as described above, and results appear in Panel C. Since the presence of a report from the district is not significantly correlated with salary, I omit it from this section. F-tests on the instruments in the first stage regressions reveal that the state fixed effects are always significant at the 1\% level, and are particularly strong instruments for state sanctions and required goals. There is now more significant variation across quantiles for all three accountability measures, and the negative relationships remain. The most negative results appear for the (conditionally) highest-paid principals. On the other hand, there is a small positive relationship between state sanctions and principal pay for the best principals. Furthermore, the 
parameters increase (are less negative/more positive) with higher quantiles, suggesting that state sanctions increase the dispersion of principal pay-which likely an intended consequence of accountability. Nonetheless, these estimates do not provide consistent evidence in line with the goal of rewarding the best and punishing the worst, since district sanctions and required goals exhibit the opposite result.

\subsection{College Attendance Rate}

Results for regressions of college attendance, as in equation 3, appear in Table 3. Conditional on school and community characteristics, required goals have no significant impact, but school reports and state sanctions imply lower college attendance rates. Interestingly, the negative relationship between state sanctions and this student outcome appears quite uniform throughout the estimated quantiles, rather than most strongly impacting the worst schools. A test for equality of the parameters across quantiles reveals no significant difference. Conditional on the presence of state sanctions, district sanctions imply better performance, regardless of school quality.

Coefficient estimates for additional school characteristics appear in Figure 2. Substantial variation exists across quantiles of the conditional distribution of college attendance rate, mirroring results in previous studies of test score gains. For instance, the impact of increased per-pupil expenditure is more positive at lower quantiles than for the more highly-performing schools. The negative impact of poverty, as measured by lunch program eligibility, is strong for all schools. The impact of size also appears more positive for the lowest quality schools, and differs substantially from OLS estimates. Furthermore, higher minority enrolment is correlated with better college matriculation among the conditionally best schools. High pupil-teacher ratios appear similarly detrimental to all but the highest quality secondary schools. Finally, a well-educated community implies better outcomes, though mostly among median schools. 
I next incorporate measures for environmental factors that may constrain principals from significantly improving school performance. Some possible constraints include low autonomy in hiring, little parental involvement, and barriers to dismissing teachers. Results appear in Panel B of Table 3. Controls include influence and parental involvement (as in salary regressions above), as well as the presence of a bargaining agreement with teachers, rating of teaching staff, barriers to dismissing poor teachers, and whether the principal's main goal is academic excellence. The impact of accountability on college attendance is only somewhat altered by these characteristics. A possible predictor for strong performance among the best schools is the presence of required goals, as seen with the significant positive coefficient at the $90^{\text {th }}$ quantile. In addition, the effect of state sanctions is most negative at the median, not the tails. Principal autonomy also hinders performance at the median of (conditional) school quality. Alternatively, problems with parental involvement are also negatively correlated with school performance, though only at better schools, suggesting that poor parental involvement has a stronger impact on otherwise strong schools.

Additional specifications control for endogeneity in accountability and school performance. Only school reports and state sanctions appear both significant and endogenous, so they are the focus here. Again, F-tests on the state fixed effect instruments in reduced form regressions for state sanctions and reports from the district reject the null at 1\%. Results in Table 3 Panel $\mathrm{C}$ reveal that school reports from the district coincide with lower performance for only the worst schools. This could certainly reflect that only the struggling schools receive performance reports. On the other hand, state sanctions maintain a negative relationship with college attendance throughout the entire distribution. This is not evidence supporting the notion that sanctions improve school performance.

\subsection{Retention Rates}

Regression estimates for the impact of accountability on retention rates (equation 3) appear in Table 4. OLS results suggest that required goals occur with lower retention rates, though that is 
not well-supported in quantile regression estimates. On the other hand, state sanctions are correlated with better retention at the worst schools and have the opposite effect on the best. District sanctions yield similar results. Schools at or just below the median experience higher retention in the presence of sanctions, but above the relationship is negative above the median. Tests of the parameters across quantiles reveal significant differences in the relationship between sanctions and school performance.

Additional covariates explain some of the magnitude of these relationships, but lead to few changes, as seen in Panel B. Results suggest that the principal's environment significantly affects performance. For instance, influence on hiring coincides with retention problems, particularly at the worst schools. The presence of a bargaining agreement (reflecting a principal's difficulty dismissing poor teachers) is related to lower retention at struggling schools. Perhaps unsurprisingly, problems with parental involvement coincide with (and likely explain) lower retention rates at the worst schools.

Endogeneity is again suspected in this specification. District sanction indicators are not significant and endogenous in this particular specification, and they are omitted here. Two-stage techniques, again using state fixed effects as instruments, reveal that accountability significantly correlates with retention. As above, F-tests on the instruments in each reduced form accountability model result in rejecting the null at the $1 \%$ level. 2SLS results display a negative relationship with reports from the district and state sanctions, while required goals occur with better performance. On the other hand, in quantile regression results, receiving a report from the district coincides with lower retention among the worst schools-arguably those intended to benefit the most. There is nonetheless some evidence that struggling schools may benefit from accountability. Required goals and state sanctions are positively correlated with retention rates at otherwise low-performing schools. 


\section{Conclusion}

In this study I investigate whether secondary school principals appear to act as agents for parents, school boards, and communities. State sanctions correspond to more negative salaries for the worst principals and higher salaries for the best, suggesting that these sanctions may be an effective reward/punish system. On the other hand, I find that other accountability measures correspond to lower salaries, particularly for the best principals, suggesting that strong performance may not be well-rewarded in this labor market. For an agent— the school principal—-to see a strong incentive, performance must be rewarded, and principals subject to accountability should receive higher salaries if they manage their schools well.

Additional evidence on college attendance rates also runs counter to a principal-agent explanation. State sanctions and reports from the district are negatively correlated with this outcome among all schools, whether they are relatively low- or high- quality. Therefore, accountability may not induce principals to work toward sending more graduates to college. However, it appears that principals may act as agents in reducing drop-out problems. Required goals and state sanctions are positively correlated with HS retention at otherwise struggling schools.

These apparently contradictory findings could reflect the nature of accountability. If educators are indeed asked to "leave no child behind," incentives would focus on weaker students, including those in danger of dropping out of school. There is no similar incentive to improve educational outcomes for stronger students, including otherwise "average" students who may or may not pursue a college education. The result that accountability correlates negatively with principal salaries (for the best principals) is exceptionally puzzling. Perhaps high-performing principals are more likely to be assigned to schools that face substantial accountability standards but have relatively low resources and low pay. Perhaps, like many teachers, the best principals are not 
motivated by money, but by their ability to positively impact students. In order to more carefully examine these issues, longitudinal data would be particularly beneficial. Unobserved principal and school characteristics are likely very important in determining a principal's pay and performance. 


\section{References}

Amemiya, Takeshi. 1982. "Two Stage Least Absolute Deviations Estimators.” Econometrica, Vol. 50, No. 3, pp. 689-712.

Arias, Omar, Kevin F. Hallock, and Walter Sosa-Escudero, 2001. "Individual Heterogeneity in the Returns to Schooling: Instrumental Variables Quantile Regression Using Twins Data.” Empirical Economics, Vol. 26, No. 1, pp. 7-40.

Ballou, Dale, and Michael Podgursky, 1995. "What Makes a Good Principal? How Teachers Assess the Performance of Principals.” Economics of Education Review, Vol. 14, No. 3, pp. 243-52.

Billger, Sherrilyn M. 2003. "Variation in the Rewards for a Teacher's Performance: An Application of Quantile Regressions.” Developments in School Finance, 2001-2002 NCES 2003403., pp.77-89.

Bound, John, David A. Jaeger, and Regina M. Baker, 1995. "Problems with Instrumental Variables Estimation When the Correlation between the Instruments and the Endogenous Explanatory Variable is Weak.” Journal of the American Statistical Association, Vol. 90 No. 430, pp. 443-50.

Brewer, Dominic J., 1993. "Principals and Student Outcomes: Evidence from U.S. High Schools." Economics of Education Review, Vol. 12, No. 4, pp. 281-92.

Chubb, John E., and Terry M. Moe, 1988. "Politics, Markets, and the Organization of Schools." The American Political Science Review, Vol. 82, No. 4, pp. 1065-87.

Cooley, Van E., and Jianping Shen, 2003. "School Accountability and Professional Job

Responsibilities: A Perspective from Secondary Principals.” Bulletin, Vol. 87, No. 634, pp. 10-25.

Eberts, Randall W., and Joe A. Stone, 1988. "Student Achievement in Public Schools: Do Principals Make a Difference?” Economics of Education Review, Vol. 7, No. 3, pp. 291-9.

Ehrenberg, Ronald G, Richard P. Chaykowski, and Randy A. Ehrenberg, 1988. "Determinants of the Compensation and Mobility of School Superintendents." Industrial and Labor Relations Review, Vol. 41, No. 3, April, pp. 386-401.

Eide, Eric, and Mark H. Showalter, 1998. "The Effect of School Quality on Student Performance: A Quantile Regression Approach.” Economics Letters, Vol. 58, No. 3, pp. 345-50.

Figlio, David N., 1999. "Functional Form and the Estimated Effects of School Resources." Economics of Education Review, Vol. 18, No. 2, pp. 241-52.

Friedkin, Noah E., and Michael R. Slater, 1994. "School Leadership and Performance: A Social Network Approach.” Sociology of Education, Vol. 67, No. 2, pp. 139-57.

Gibbons, Robert, and Kevin J. Murphy, 1990. "Relative Performance Evaluation for Chief Executive Officers.” Industrial and Labor Relations Review, Vol. 43, No. 3, pp. s30-s51. 
Hallock, Kevin F., Regina Madalozzo, and Clayton G. Reck, 2004. "Uncovering Heterogeneity in Managerial Pay - Firm Performance Relationships Using Quantile Regression.” working paper.

Hallock, Kevin F., 2002. "Managerial Pay and Governance in American Nonprofits.” Industrial Relations, Vol. 41, No. 3, pp. 377-406.

Hallock, Kevin F., and Kevin J. Murphy, 1999. The Economics of Executive Compensation, Edward Elgar Publishing Limited, Massachusetts.

Hanushek, Eric A., Steven G. Rivkin, and Lori L. Taylor, 1996. "Aggregation and the Estimated Effects of School Resources.” The Review of Economics and Statistics, Vol. 78, No. 4, pp. 611-27.

Jacobson, Stephen L., 1989. “The Effects of Pay Incentives on Teacher Absenteeism.” The Journal of Human Resources, Vol. 24, No. 2, pp. 280-6.

Jensen, Michael C., and Kevin J. Murphy, 1990. "Performance Pay and Top-Management Incentives.” Journal of Political Economy, Vol. 98, No.2, April, pp. 225-64.

Koenker, Roger, and Kevin F. Hallock, 2001. “Quantile Regression.” Journal of Economic Perspectives, Vol. 15, No. 4, pp. 143-56.

Koenker, Roger, and Gilbert Bassett, Jr., 1978. "Regression Quantiles.” Econometrica, Vol. 46, No. 1, pp. 33-50.

Ladd, Helen F., 1999. “The Dallas School Accountability and Incentive Program: An Evaluation of Its Impacts on Student Outcomes.” Economics of Education Review, Vol. 18, No. 1, pp. 1-16.

Levin, Jesse, 2001. "For Whom the Reductions Count: A Quantile Regression Analysis of Class Size and Peer Effects on Scholastic Achievement." Empirical Economics, Vol. 26, No. 1,pp. 221-46.

Meier, Kenneth J., and Laurence J. O’Toole, Jr., 2002. "Public Management and Organizational Performance: The Effect of Managerial Quality.” Journal of Policy Analysis and Management, Vol. 21, No. 4, pp. 629-43.

Palmer, Jason S., 2002. “The Effects of Accountability Reform on Testing Frequency and Student Performance: A Two-Stage, Quasi-Experimental Approach.” working paper.

Schultz, T. Paul, and Germano Mwabu, 1998. "Labor Unions and the Distribution of Wages and Employment in South Africa." Industrial and Labor Relations Review, Vol. 51, No. 4, pp. 680-703.

Stock, James H., and Motohiro Yogo. 2005. "Testing for Weak Instruments in Linear IV Regression.” In Donald W.K. Andrews and James H. Stock eds., Identification and Inference for Econometric Models: Essays in Honor of Thomas Rothenberg. New York: Cambridge University Press, pp. 80-108.

Stone, Joe A., 1985. "Determinants of Administrators' Salaries in Public Schools: Differences for Men and Women.” Economics of Education Review, Vol. 4, No. 2, pp. 105-9. 
Figure 1. OLS and Quantile Regression Parameter Estimates for Effects on $\ln ($ Principal's Salary)
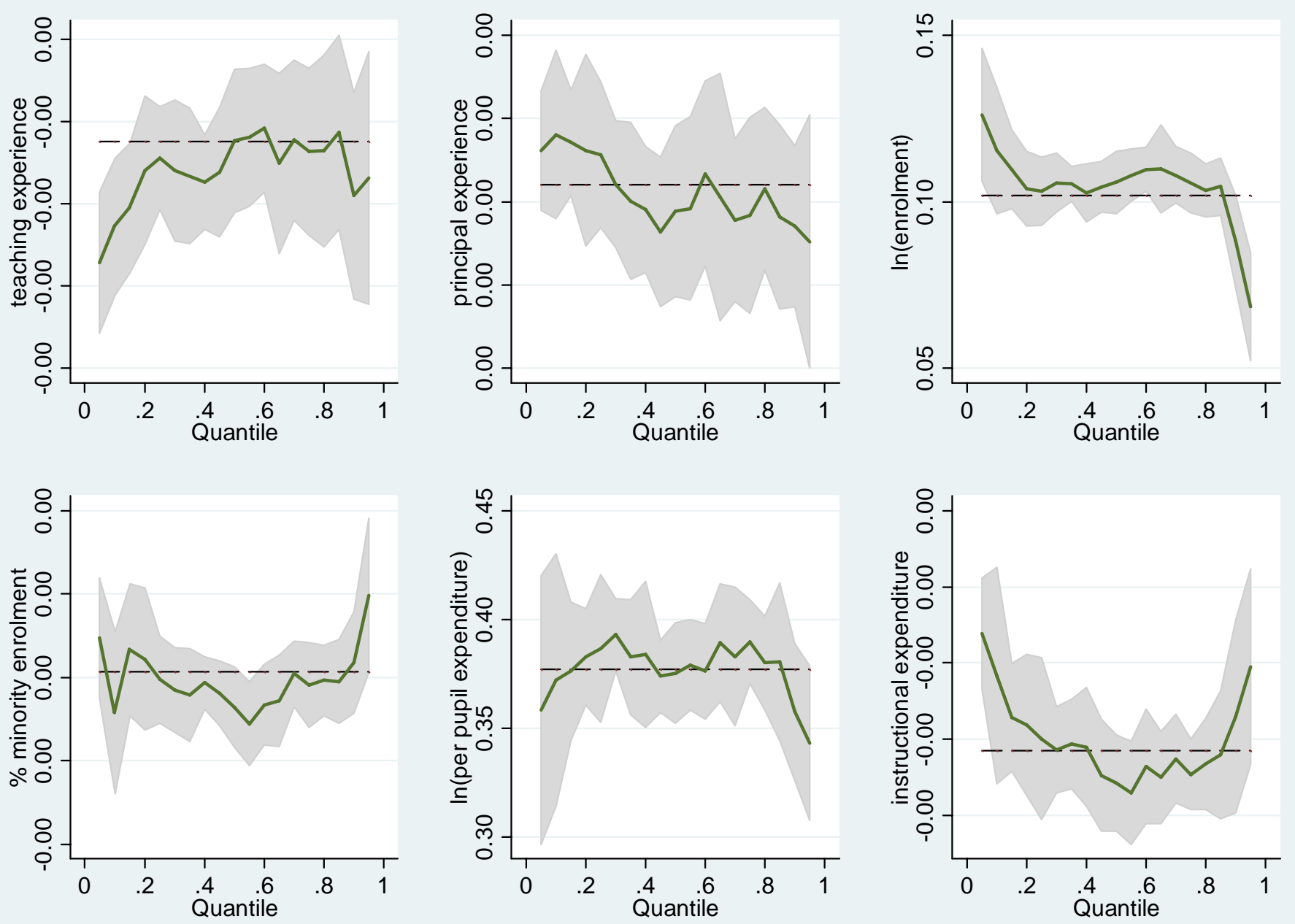

Data: Public Secondary Schools from 1999-2000 SASS, 2000 U.S. Census. Quantiles along the x-axis represent quantiles in the conditional distribution of $\ln$ (principal salary). The dotted lines reveal OLS parameter estimates. Quantile regression estimates are presented with 95\% confidence intervals. Additional regressors are as defined in the text in equation (2). 
Figure 2. OLS and Quantile Regression Parameter Estimates for Effects on College Attendance Rate
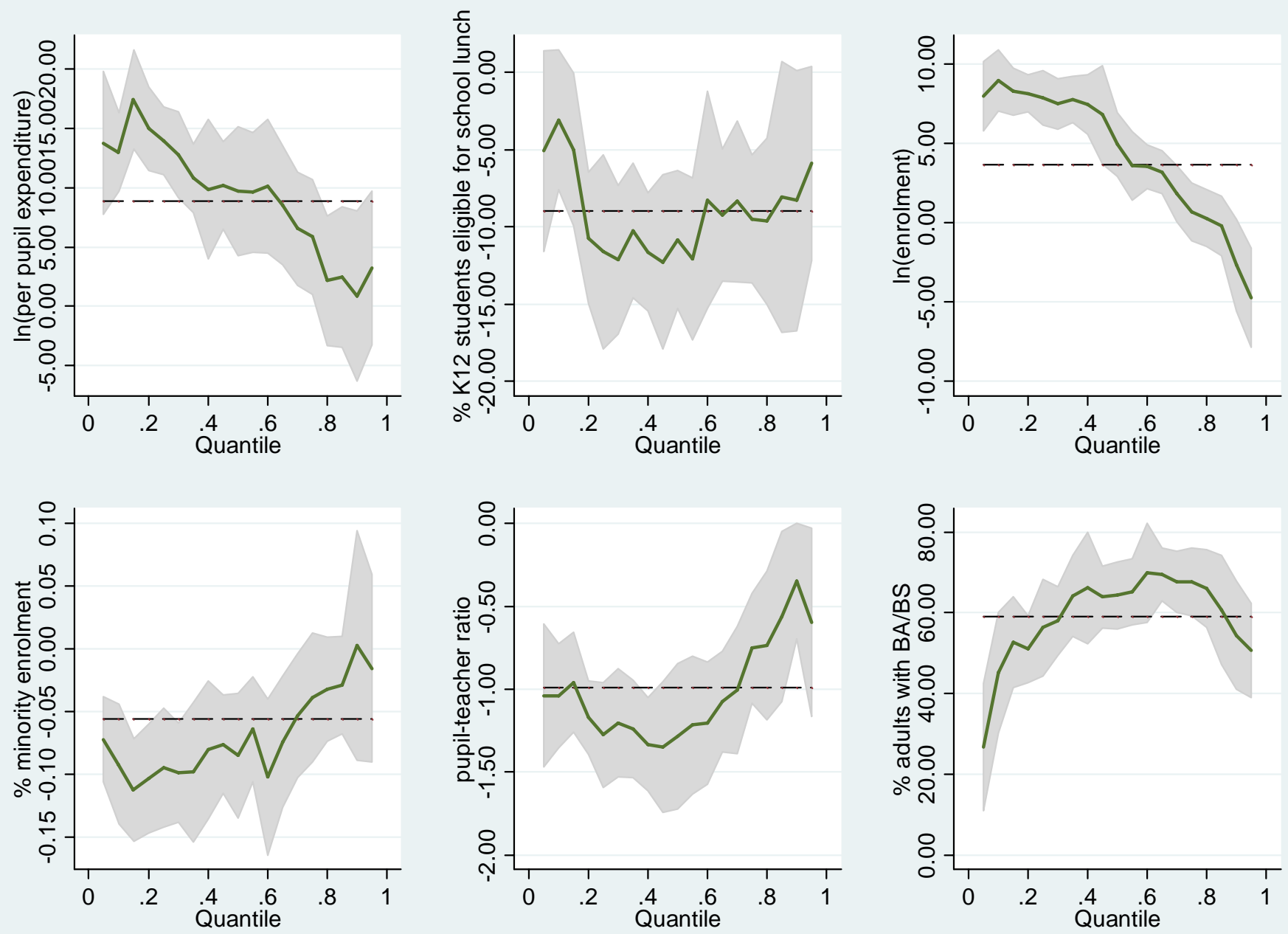

Data: Public Secondary Schools from 1999-2000 SASS, 2000 U.S. Census. Quantiles along the x-axis represent quantiles in the conditional distribution of $\ln$ (principal salary). The dotted lines reveal OLS parameter estimates. Quantile regression estimates are presented with 95\% confidence intervals. Additional regressors are as defined in the text in equation (3). 
Table 1. Summary Statistics for Principals and Their Secondary Schools

\begin{tabular}{lrr} 
Variable Name & Mean & St. Dev. \\
\hline Principal Salary & 67028.76 & 15432.940 \\
Teaching Experience & 13.727 & 7.270 \\
Principal Experience & 8.580 & 7.751 \\
Enrolment & 729.410 & 585.429 \\
Pupil-Teacher Ratio & 14.753 & 4.170 \\
\% Minority Enrolment & 26.602 & 30.386 \\
\% Expenditures for Instruction & 52.970 & 7.158 \\
Core Expenditures per pupil & 4185.01 & 1241.048 \\
\% HH with children & 0.347 & 0.075 \\
\% adult population with BA/BS & 0.196 & 0.127 \\
School Required to Meet Goals & 0.809 & 0.393 \\
School Receives Report from District & 0.946 & 0.226 \\
Serious Problems with Parental Involvement & 0.156 & 0.363 \\
Principal's Influence: & & \\
exceeds district's on performance standards & 0.497 & 0.500 \\
exceeds district's on hiring teachers & 0.687 & 0.464 \\
exceeds teachers' on hiring teachers & 0.762 & 0.426 \\
Percent of graduates attend 4-year college & 41.590 & 21.447 \\
9-12 grade drop-out rate & 6.596 & 26.729
\end{tabular}

Data: National Center for Education Statistics: Schools and Staffing Survey 1999-2000, 2000 Common Core of Data; 2000 U.S. Census.

Based upon bootstrap sample of 5000 observations, generated with NCES sampling weights. 
Table 2. School Accountability and Principal Salaries

\begin{tabular}{|c|c|c|c|c|c|c|c|}
\hline Panel A. DepVar $=\ln ($ principal salary $)$ & OLS & Q 0.1 & Q 0.25 & Q 0.5 & Q 0.75 & Q 0.9 & $\begin{array}{l}\text { Test Across } \\
\text { Quantiles }^{a}\end{array}$ \\
\hline School Required to Meet Goals & $\begin{array}{l}-0.015^{* * *} \\
(0.005)\end{array}$ & $\begin{array}{l}0.004 \\
(0.011)\end{array}$ & $\begin{array}{l}-0.023 * * * \\
(0.008)\end{array}$ & $\begin{array}{l}-0.015^{* * *} \\
(0.005)\end{array}$ & $\begin{array}{l}-0.010^{*} \\
(0.006)\end{array}$ & $\begin{array}{l}-0.019 * * \\
(0.009)\end{array}$ & $2.28^{*}$ \\
\hline School Receives Report from District & $\begin{array}{l}0.013 \\
(0.008)\end{array}$ & $\begin{array}{l}-0.016 \\
(0.015)\end{array}$ & $\begin{array}{l}0.014 \\
(0.012)\end{array}$ & $\begin{array}{l}0.015^{*} \\
(0.008)\end{array}$ & $\begin{array}{l}0.029 * * * \\
(0.010)\end{array}$ & $\begin{array}{l}0.001 \\
(0.013)\end{array}$ & $2.81 * *$ \\
\hline State Sanctions Schools for Poor Performance & $\begin{array}{l}-0.009 * * \\
(0.004)\end{array}$ & $\begin{array}{l}-0.028^{* * *} \\
(0.009)\end{array}$ & $\begin{array}{l}-0.014 * * \\
(0.006)\end{array}$ & $\begin{array}{l}-0.007 \\
(0.005)\end{array}$ & $\begin{array}{l}-0.013^{* *} \\
(0.005)\end{array}$ & $\begin{array}{l}-0.001 \\
(0.007)\end{array}$ & $2.17^{*}$ \\
\hline District Sanctions Schools for Poor Performance & $\begin{array}{l}-0.013^{* *} \\
(0.005)\end{array}$ & $\begin{array}{l}-0.037^{* *} \\
(0.015)\end{array}$ & $\begin{array}{l}-0.022^{* * *} \\
(0.008)\end{array}$ & $\begin{array}{l}-0.004 \\
(0.007)\end{array}$ & $\begin{array}{l}0.010 \\
(0.007)\end{array}$ & $\begin{array}{l}0.004 \\
(0.008)\end{array}$ & $3.56^{* * *}$ \\
\hline R-squared & 0.718 & & & & & & \\
\hline Panel B. DepVar $=\ln ($ principal salary $)$ & OLS & Q 0.1 & Q 0.25 & Q 0.5 & Q 0.75 & Q 0.9 & \\
\hline School Required to Meet Goals & $\begin{array}{l}-0.015^{* * *} \\
(0.005)\end{array}$ & $\begin{array}{l}-0.001 \\
(0.010)\end{array}$ & $\begin{array}{l}-0.022 * * * \\
(0.008)\end{array}$ & $\begin{array}{l}-0.017 * * * \\
(0.005)\end{array}$ & $\begin{array}{l}-0.015^{* *} \\
(0.006)\end{array}$ & $\begin{array}{l}-0.005 \\
(0.009)\end{array}$ & 1.55 \\
\hline School Receives Report from District & $\begin{array}{l}0.013 \\
(0.008)\end{array}$ & $\begin{array}{l}-0.002 \\
(0.013)\end{array}$ & $\begin{array}{l}0.015 \\
(0.011)\end{array}$ & $\begin{array}{l}0.015 \\
(0.009)\end{array}$ & $\begin{array}{l}0.019 * \\
(0.011)\end{array}$ & $\begin{array}{l}0.026^{*} \\
(0.013)\end{array}$ & 0.64 \\
\hline State Sanctions Schools for Poor Performance & $\begin{array}{l}-0.010 * * \\
(0.004)\end{array}$ & $\begin{array}{l}-0.024 * * * \\
(0.008)\end{array}$ & $\begin{array}{l}-0.012^{* *} \\
(0.006)\end{array}$ & $\begin{array}{l}-0.009 * \\
(0.005)\end{array}$ & $\begin{array}{l}-0.018^{* * *} \\
(0.006)\end{array}$ & $\begin{array}{l}0.009 \\
(0.007)\end{array}$ & $4.93^{* * *}$ \\
\hline District Sanctions Schools for Poor Performance & $\begin{array}{l}-0.013^{* *} \\
(0.005)\end{array}$ & $\begin{array}{l}-0.041^{* * *} \\
(0.013)\end{array}$ & $\begin{array}{l}-0.022^{* *} \\
(0.009)\end{array}$ & $\begin{array}{l}-0.005 \\
(0.007)\end{array}$ & $\begin{array}{l}0.005 \\
(0.008)\end{array}$ & $\begin{array}{l}-0.004 \\
(0.008)\end{array}$ & $3.23^{* * *}$ \\
\hline $\begin{array}{l}\text { Principal's Influence: } \\
\text { exceeds district's on performance standards }\end{array}$ & $\begin{array}{l}0.005 \\
(0.004)\end{array}$ & $\begin{array}{c}-0.014 * \\
(0.008)\end{array}$ & $\begin{array}{l}-0.006 \\
(0.006)\end{array}$ & $\begin{array}{l}0.001 \\
(0.005)\end{array}$ & $\begin{array}{l}0.001 \\
(0.005)\end{array}$ & $\begin{array}{l}0.033^{* * *} \\
(0.006)\end{array}$ & $9.76^{* * *}$ \\
\hline exceeds district's on hiring teachers & $\begin{array}{l}-0.004 \\
(0.004)\end{array}$ & $\begin{array}{l}-0.002 \\
(0.010)\end{array}$ & $\begin{array}{l}0.004 \\
(0.006)\end{array}$ & $\begin{array}{l}0.002 \\
(0.006)\end{array}$ & $\begin{array}{l}-0.017 * * * \\
(0.006)\end{array}$ & $\begin{array}{l}-0.015^{* *} \\
(0.007)\end{array}$ & $3.28 * *$ \\
\hline exceeds teachers' on hiring teachers & $\begin{array}{l}0.009 * * \\
(0.004)\end{array}$ & $\begin{array}{l}0.002 \\
(0.009)\end{array}$ & $\begin{array}{l}0.012^{*} \\
(0.007)\end{array}$ & $\begin{array}{l}0.015 * * \\
(0.006)\end{array}$ & $\begin{array}{l}0.007 \\
(0.006)\end{array}$ & $\begin{array}{l}0.010 \\
(0.008)\end{array}$ & 0.86 \\
\hline Serious problem with parental involvement & $\begin{array}{l}0.019 * * * \\
(0.005)\end{array}$ & $\begin{array}{l}-0.0005 \\
(0.013)\end{array}$ & $\begin{array}{l}0.007 \\
(0.009)\end{array}$ & $\begin{array}{l}0.021 * * \\
(0.009)\end{array}$ & $\begin{array}{l}0.021 * * \\
(0.009)\end{array}$ & $\begin{array}{l}0.056^{* * *} \\
(0.014)\end{array}$ & $3.21 * *$ \\
\hline R-squared & 0.721 & & & & & & \\
\hline
\end{tabular}


Table 2. School Accountability and Principal Salaries, Continued

\begin{tabular}{|c|c|c|c|c|c|c|c|}
\hline Panel C. DepVar $=\ln$ (principal salary) & 2SLS & Q 0.1 & Q 0.25 & Q 0.5 & Q 0.75 & Q 0.9 & Quantiles $^{a}$ \\
\hline School Required to Meet Goals & $\begin{array}{l}-0.032 \\
(0.020)\end{array}$ & $\begin{array}{l}0.024 \\
(0.033)\end{array}$ & $\begin{array}{l}-0.015 \\
(0.026)\end{array}$ & $\begin{array}{l}-0.034 \\
(0.028)\end{array}$ & $\begin{array}{l}-0.058^{* *} \\
(0.024)\end{array}$ & $\begin{array}{l}-0.100 * * * \\
(0.027)\end{array}$ & $2.32 *$ \\
\hline State Sanctions Schools for Poor Performance & $\begin{array}{l}-0.016 * \\
(0.009)\end{array}$ & $\begin{array}{l}-0.037 * * \\
(0.019)\end{array}$ & $\begin{array}{l}-0.036 * * * \\
-(0.108)\end{array}$ & $\begin{array}{l}-0.025^{* *} \\
(0.011)\end{array}$ & $\begin{array}{l}-0.005 \\
(0.012)\end{array}$ & $\begin{array}{l}0.045^{* * *} \\
(0.013)\end{array}$ & $6.21 * * *$ \\
\hline District Sanctions Schools for Poor Performance & $\begin{array}{l}-0.114^{* * *} \\
(0.022)\end{array}$ & $\begin{array}{l}-0.145^{* * *} \\
(0.034)\end{array}$ & $\begin{array}{l}0.030^{* * *} \\
(0.025)\end{array}$ & $\begin{array}{l}-0.068^{* * *} \\
(0.025)\end{array}$ & $\begin{array}{l}-0.137^{* * *} \\
(0.030)\end{array}$ & $\begin{array}{l}-0.196 * * * \\
(0.030)\end{array}$ & $4.06^{* * *}$ \\
\hline
\end{tabular}

***, $* *$, and $*$ denote significance at the $0.01,0.05$, and 0.10 level, respectively.

NCES sampling weights were incorporated into bootstrap samples with 5000 principals. Robust standard errors are reported,

and quantile regression estimates result from 1000 bootstrap repetitions. Additional regressors are as reported in section 3 of the text.

a F-statistic for testing null hypothesis that parameter estimates are equal across quantiles $0.1,0.25,0.5,0.75$, and 0.9 . 
Table 3. School Accountability and College Attendance Rates

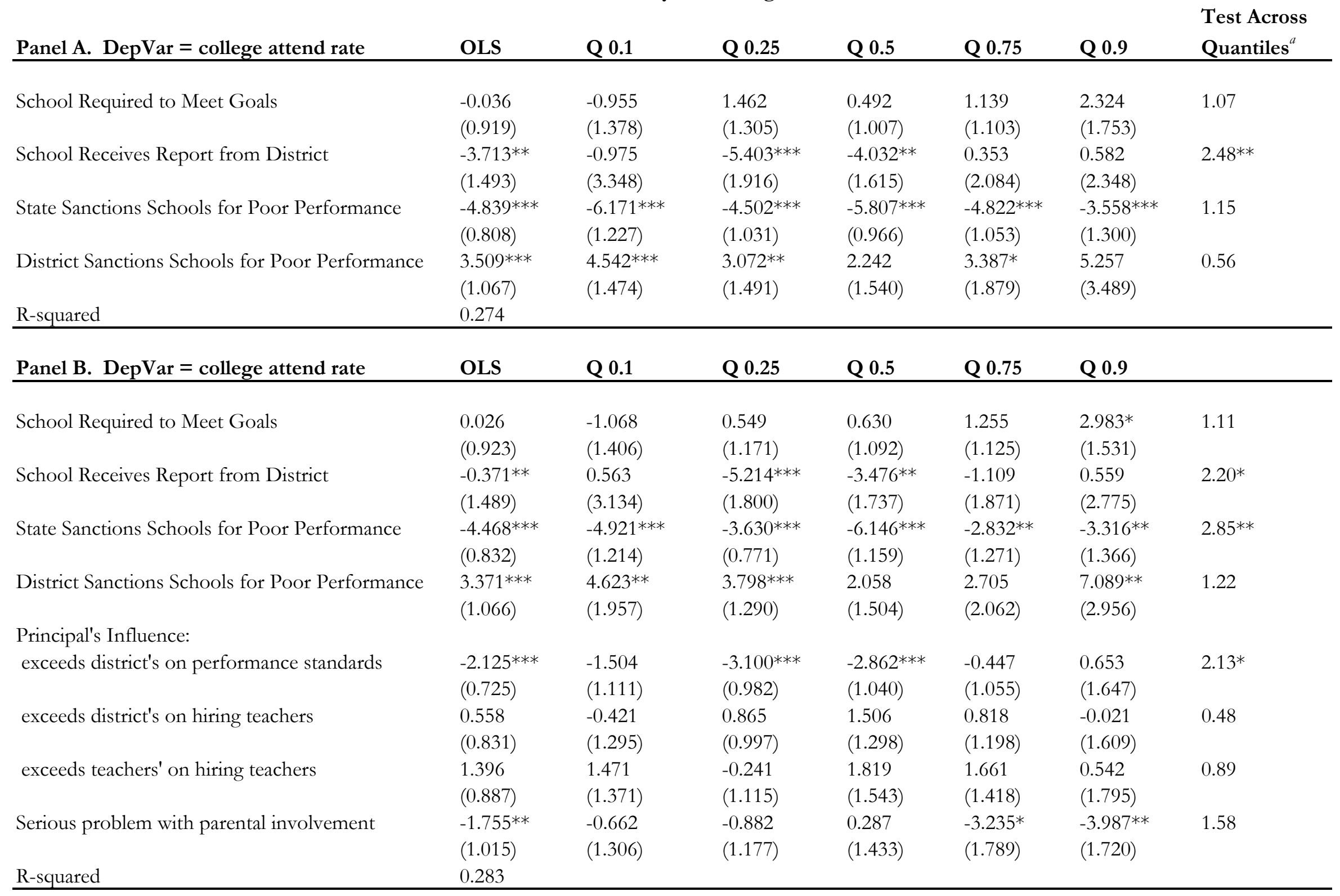


Table 3. School Accountability and College Attendance Rates, Continued

\begin{tabular}{|c|c|c|c|c|c|c|c|}
\hline Panel C. DepVar = college attend rate & 2SLS & Q 0.1 & Q 0.25 & Q 0.5 & Q 0.75 & Q 0.9 & \\
\hline School Receives Report from District & $\begin{array}{l}-18.502^{* * *} \\
(6.550)\end{array}$ & $\begin{array}{l}-25.903^{* * *} \\
(9.648)\end{array}$ & $\begin{array}{l}19.561 \\
(12.964)\end{array}$ & $\begin{array}{l}-9.322 \\
(13.953)\end{array}$ & $\begin{array}{l}-16.270 \\
(16.212)\end{array}$ & $\begin{array}{l}1.224 \\
(18.869)\end{array}$ & 0.69 \\
\hline State Sanctions Schools for Poor Performance & $\begin{array}{l}-6.039 * * * \\
(1.284)\end{array}$ & $\begin{array}{l}-7.311 * * * \\
(1.997)\end{array}$ & $\begin{array}{l}-6.790 * * * \\
(1.619)\end{array}$ & $\begin{array}{l}-8.727 * * * \\
(1.975)\end{array}$ & $\begin{array}{l}-4.575^{* *} \\
(2.114)\end{array}$ & $\begin{array}{l}-4.732^{* * * *} \\
(2.941)\end{array}$ & 1.13 \\
\hline
\end{tabular}

***, **, and $*$ denote significance at the $0.01,0.05$, and 0.10 level, respectively.

NCES sampling weights were incorporated into bootstrap samples with 5000 principals. Robust standard errors are reported,

and quantile regression estimates result from 1000 bootstrap repetitions. Additional regressors are as reported in section 3 of the text.

a F-statistic for testing null hypothesis that parameter estimates are equal across quantiles $0.1,0.25,0.5,0.75$, and 0.9 . 
Table 4. School Accountability and Retention Rates ${ }^{a}$

\begin{tabular}{|c|c|c|c|c|c|c|c|}
\hline Panel A. DepVar = drop out rate & OLS & Q 0.1 & Q 0.25 & Q 0.5 & Q 0.75 & Q 0.9 & $\begin{array}{l}\text { Test Across } \\
\text { Quantiles }^{b} \\
\end{array}$ \\
\hline School Required to Meet Goals & $\begin{array}{l}-0.359 * * * \\
(0.124)\end{array}$ & $\begin{array}{l}-0.086 \\
(0.077)\end{array}$ & $\begin{array}{l}-0.015 \\
(0.028)\end{array}$ & $\begin{array}{l}0.027^{*} \\
(0.016)\end{array}$ & $\begin{array}{l}0.028 \\
(0.017)\end{array}$ & $\begin{array}{l}0.012 \\
(0.010)\end{array}$ & 1.26 \\
\hline School Receives Report from District & $\begin{array}{l}-0.158 \\
(0.219)\end{array}$ & $\begin{array}{l}0.131 \\
(0.169)\end{array}$ & $\begin{array}{l}0.064 \\
(0.081)\end{array}$ & $\begin{array}{l}0.009 \\
(0.024)\end{array}$ & $\begin{array}{l}0.056^{* * *} \\
(0.021)\end{array}$ & $\begin{array}{l}0.029 \\
(0.024)\end{array}$ & 1.47 \\
\hline State Sanctions Schools for Poor Performance & $\begin{array}{l}0.517^{* * *} \\
(0.105)\end{array}$ & $\begin{array}{l}0.238^{* * *} \\
(0.057)\end{array}$ & $\begin{array}{l}0.037 \\
(0.026)\end{array}$ & $\begin{array}{l}0.046^{* * *} \\
(0.015)\end{array}$ & $\begin{array}{l}-0.0001 \\
(0.016)\end{array}$ & $\begin{array}{l}-0.032^{* * *} \\
(0.009)\end{array}$ & $10.35^{* * *}$ \\
\hline District Sanctions Schools for Poor Performance & $\begin{array}{l}-0.034 \\
(0.133)\end{array}$ & $\begin{array}{l}-0.078 \\
(0.152)\end{array}$ & $\begin{array}{l}0.045^{*} \\
(0.026)\end{array}$ & $\begin{array}{l}0.046^{* * *} \\
(0.017)\end{array}$ & $\begin{array}{l}-0.027^{*} \\
(0.016)\end{array}$ & $\begin{array}{l}-0.002 \\
(0.011)\end{array}$ & $5.95^{* * *}$ \\
\hline R-squared & 0.043 & & & & & & \\
\hline Panel B. DepVar = drop out rate & OLS & Q 0.1 & Q 0.25 & Q 0.5 & Q 0.75 & Q 0.9 & \\
\hline School Required to Meet Goals & $\begin{array}{l}-0.403 * * * \\
(0.123)\end{array}$ & $\begin{array}{l}-0.057 \\
(0.061)\end{array}$ & $\begin{array}{l}-0.014 \\
(0.031)\end{array}$ & $\begin{array}{l}0.011 \\
(0.017)\end{array}$ & $\begin{array}{l}0.021 \\
(0.018)\end{array}$ & $\begin{array}{l}0.015 \\
(0.011)\end{array}$ & 0.51 \\
\hline School Receives Report from District & $\begin{array}{l}-0.191 \\
(0.217)\end{array}$ & $\begin{array}{l}0.212 \\
(0.162)\end{array}$ & $\begin{array}{l}0.038 \\
(0.112)\end{array}$ & $\begin{array}{l}0.004 \\
(0.027)\end{array}$ & $\begin{array}{l}0.044 * \\
(0.026)\end{array}$ & $\begin{array}{l}0.050^{* * *} \\
(0.019)\end{array}$ & 1.09 \\
\hline State Sanctions Schools for Poor Performance & $\begin{array}{l}0.355^{* * *} \\
(0.108)\end{array}$ & $\begin{array}{l}0.142^{* *} \\
(0.060)\end{array}$ & $\begin{array}{l}0.011 \\
(0.032)\end{array}$ & $\begin{array}{l}0.048 * * * \\
(0.016)\end{array}$ & $\begin{array}{l}0.006 \\
(0.017)\end{array}$ & $\begin{array}{l}-0.031^{* * * *} \\
(0.009)\end{array}$ & $7.01 * * *$ \\
\hline District Sanctions Schools for Poor Performance & $\begin{array}{l}-0.033 \\
(0.132)\end{array}$ & $\begin{array}{l}-0.166 \\
(0.127)\end{array}$ & $\begin{array}{l}0.051 \\
(0.037)\end{array}$ & $\begin{array}{l}0.043^{* *} \\
(0.020)\end{array}$ & $\begin{array}{l}-0.016 \\
(0.017)\end{array}$ & $\begin{array}{l}-0.005 \\
(0.016)\end{array}$ & $3.68^{* * *}$ \\
\hline $\begin{array}{l}\text { Principal's Influence: } \\
\text { exceeds district's on performance standards }\end{array}$ & $\begin{array}{l}0.305^{* * *} \\
(0.094)\end{array}$ & $\begin{array}{l}-0.083^{*} \\
(0.050)\end{array}$ & $\begin{array}{l}-0.009 \\
(0.027)\end{array}$ & $\begin{array}{l}0.0004 \\
(0.012)\end{array}$ & $\begin{array}{l}-0.027^{* *} \\
(0.011)\end{array}$ & $\begin{array}{l}0.010 \\
(0.008)\end{array}$ & $3.98^{* * *}$ \\
\hline exceeds district's on hiring teachers & $\begin{array}{l}-0.233^{* *} \\
(0.103)\end{array}$ & $\begin{array}{l}0.102^{* *} \\
(0.046)\end{array}$ & $\begin{array}{l}0.034 \\
(0.032)\end{array}$ & $\begin{array}{l}-0.030^{* *} \\
(0.014)\end{array}$ & $\begin{array}{l}-0.001 \\
(0.013)\end{array}$ & $\begin{array}{l}0.006 \\
(0.009)\end{array}$ & $3.77 * * *$ \\
\hline exceeds teachers' on hiring teachers & $\begin{array}{l}-0.305^{* * *} \\
(0.112)\end{array}$ & $\begin{array}{l}-0.121^{* *} \\
(0.051)\end{array}$ & $\begin{array}{l}-0.153^{* * * *} \\
(0.032)\end{array}$ & $\begin{array}{l}-0.059 * * * \\
(0.014)\end{array}$ & $\begin{array}{l}-0.046^{* * *} \\
(0.012)\end{array}$ & $\begin{array}{l}-0.019 * * \\
(0.008)\end{array}$ & $4.98^{* * *}$ \\
\hline District has bargaining agreement with teachers & $\begin{array}{l}-0.691^{* * *} \\
(0.114)\end{array}$ & $\begin{array}{l}-0.330^{* * *} \\
(0.049)\end{array}$ & $\begin{array}{l}-0.113^{* * * *} \\
(0.031)\end{array}$ & $\begin{array}{l}-0.035^{* *} \\
(0.017)\end{array}$ & $\begin{array}{l}-0.021 \\
(0.016)\end{array}$ & $\begin{array}{l}0.001 \\
(0.010)\end{array}$ & $11.20 * * *$ \\
\hline Serious problem with parental involvement & $\begin{array}{l}0.057 \\
(0.134)\end{array}$ & $\begin{array}{l}-0.173^{*} \\
(0.096)\end{array}$ & $\begin{array}{l}-0.066^{*} \\
(0.040)\end{array}$ & $\begin{array}{l}-0.023 \\
(0.019)\end{array}$ & $\begin{array}{l}-0.027 \\
(0.021)\end{array}$ & $\begin{array}{l}0.009 \\
(0.017)\end{array}$ & 1.54 \\
\hline R-squared & 0.061 & & & & & & \\
\hline
\end{tabular}


Table 4. School Accountability and Retention Rates, Continued

\begin{tabular}{|c|c|c|c|c|c|c|c|}
\hline Panel C. DepVar = drop out rate & 2SLS & Q 0.1 & Q 0.25 & Q 0.5 & Q 0.75 & Q 0.9 & \\
\hline School Required to Meet Goals & $\begin{array}{l}1.296^{* * *} \\
(0.322)\end{array}$ & $\begin{array}{l}1.551^{* * *} \\
(0.334)\end{array}$ & $\begin{array}{l}0.074 \\
(0.148)\end{array}$ & $\begin{array}{l}-0.014 \\
(2.121)\end{array}$ & $\begin{array}{c}-0.094^{*} \\
(0.056)\end{array}$ & $\begin{array}{l}-0.055 \\
(0.033)\end{array}$ & $7.58^{* * *}$ \\
\hline School Receives Report from District & $\begin{array}{l}-2.852^{* * *} \\
(0.753)\end{array}$ & $\begin{array}{l}-2.972^{* * *} \\
(1.004)\end{array}$ & $\begin{array}{l}-0.653^{* *} \\
(0.292)\end{array}$ & $\begin{array}{l}-0.030 \\
(10.562)\end{array}$ & $\begin{array}{l}0.269 \\
(0.164)\end{array}$ & $\begin{array}{l}0.240^{*} \\
(0.126)\end{array}$ & $3.38^{* * *}$ \\
\hline State Sanctions Schools for Poor Performance & $\begin{array}{l}-0.713^{* * *} \\
(0.226)\end{array}$ & $\begin{array}{l}-0.075 \\
(1.004)\end{array}$ & $\begin{array}{l}0.235^{* * *} \\
(0.057)\end{array}$ & $\begin{array}{l}0.159 \\
(0.327)\end{array}$ & $\begin{array}{l}0.100^{* * *} \\
(0.023)\end{array}$ & $\begin{array}{l}-0.020 \\
(0.019)\end{array}$ & $11.67 * * *$ \\
\hline
\end{tabular}

\footnotetext{
***, **, and $*$ denote significance at the $0.01,0.05$, and 0.10 level, respectively.

NCES sampling weights were incorporated into bootstrap samples with 5000 principals. Robust standard errors are reported,

and quantile regression estimates result from 1000 bootstrap repetitions. Additional regressors are as reported in section 3 of the text.

$a$ Retention rates are calculated as 100 minus 9th through 12th grade drop-out rate.

$b$ F-statistic for testing null hypothesis that parameter estimates are equal across quantiles $0.1,0.25,0.5,0.75$, and 0.9 .
} 